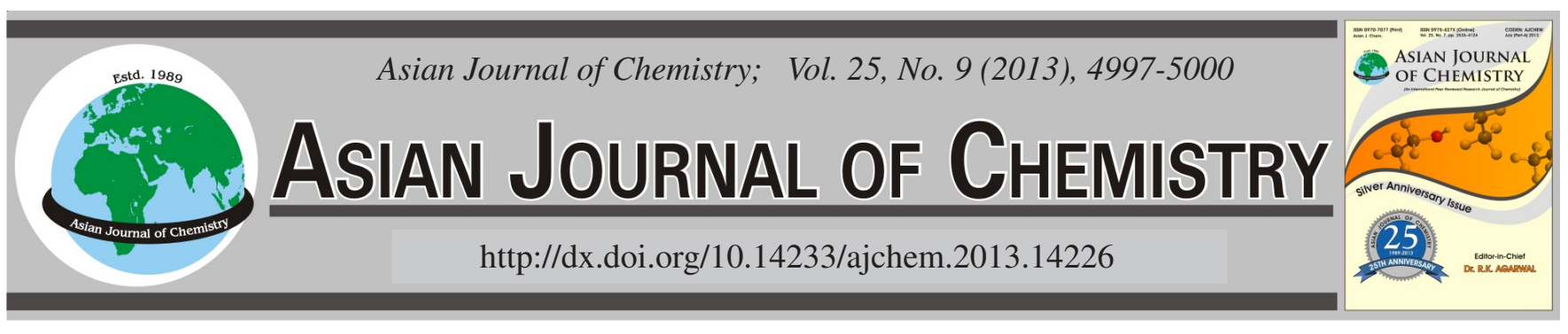

\title{
Antioxidant and Antiinflammatory Activities of Different Solvent Extracts and Isolated Compounds of Ipomoea pes-caprae (L) Sweet of Sunderban Mangrove Eco-complex
}

\author{
D. Banerjee ${ }^{1, *}$, A.K. Hazra ${ }^{1}$, T. Seal ${ }^{2}$, T. Sur ${ }^{3}$, D. Bhattacharya ${ }^{3}$, J. Ray $^{1}$, A. Mukherjee $^{4}$ and B. Mukherjee ${ }^{1, *}$
}

${ }^{1}$ S.N. Pradhan Centre for Neurosciences, University of Calcutta, Kolkata-700 020, India

${ }^{2}$ Botanical Survey of India, Indian Botanic Garden, Howrah-711 103, India

${ }^{3}$ Department of Pharmacology, Institute of Postgraduate Medical Education \& Research, Kolkata-700 020, India

${ }^{4}$ School of Oceanographic Studies, Jadavpur University, Kolkata-700 032, India

*Corresponding author: Fax: +91 33 23502224; E-mail: mukherjee.biswapati@gmail.com; dbanerjee1979@gmail.com

\begin{abstract}
In the present study, we carried out for the first time the antioxidant and antiinflammmatory activities of the different solvent extracts of the plant Ipomoea pes-caprae (L) sweet grown up in the marine enviornment of the Sunderban Mangrove eco-complex. It was observed that chloroform and ethyl acetate solvent extracts obtained from the methanolic extract of the plant had significant antioxidant and antiinflammatory activities. To trace the molecules responsible for these bioactivities, the chemical investigation of the plant yielded four pure compounds, 7-hydroxy-6-methoxycoumarin; 5,7,4'-trimethoxykaempferol; 3,7,8,3'4'-pentahydroxy flavone; trans-[3-(4'hydroxyphenyl)-2-propenoic acid] which were identified by spectral methods. These compounds when tested individually, showed appreciable radical scavenging activities.
\end{abstract}

Key Words: Ipomoea pes-caprae, Antioxidant activity, Antiinflammatory activity.

\section{INTRODUCTION}

Ipomoea pes-caprae (L) sweet belonging to the family Convolvulaceae are widely distributed in tropical and subtropical countries. Some of the species belonging to the genus Ipomoea are frequently used in folk medicine for the treatment of several diseases ${ }^{1,2}$. It had been employed as a herbal remedy in countries like Brazil, Mexico, Thailand, India to cure inflammations, colonic, diuretic disorders, gonorrhoea, dolorous processes ${ }^{3,4}$. I. pes-caprae is known as Rinonina in Mexico which is used as infusions for kidney ailments and as decoctions to treat functional digestive disorders, colic, dysentery, internal-external pain and inflammatory conditions ${ }^{5}$. Pre-clinical and clinical investigations have confirmed some pharmacological properties ${ }^{6-9}$ of this plant, but no systematic pharmacological and chemical work was done on this species, particularly grown up in the struggling marine environment of the Sunderban mangrove eco-complex where it is used for the prevention of rheumatoid arthritis ${ }^{10}$. This prompted the present investigator to study the antioxidant and antiinflammatory activities of the plant to establish the scientific basis of such application and to identify the chemical entities responsible for such activities.

\section{EXPERIMENTAL}

The UV spectra were recorded in UV-visible spectrophotometer (Ultrospec 2000, Pharmacia Biotech). IR spectra were obtained in $\mathrm{KBr}$ on a Perkin-Elmer 599 B spectrophotometer. The NMR spectra were recorded in $\mathrm{CDCl}_{3} / \mathrm{MeOD}_{4}$ using a Bruker AV-300 spectrometer (300 MHz for ${ }^{1} \mathrm{H}$ NMR and 75 $\mathrm{MHz}$ for ${ }^{13} \mathrm{C}$ and DEPT). Electron-impact mass spectrometry (EIMS), FAB and HRMS data were recorded using ShimadzuQP5050A, JEOL JMS600 and Qtof Micro YA263, respectively.

The aerial part of Ipomoea pes-caprae was collected from Sagar Island $\left(21^{\circ} 56^{\prime} \mathrm{N}, 88^{\circ} 16^{\prime} \mathrm{E}\right)$ of the Sunderban mangrove eco-complex (West Bengal, India) during December 2008. The voucher specimen (CU1/046) was authenticated by Botanical Survey of India (BSI), Howrah, West Bengal, India and preserved in our laboratory.

Extraction, isolation and characterization: The airdried and powdered aerial part of I. pes-caprae $(750 \mathrm{~g})$ was soaked in methanol $(5.5 \mathrm{~L})$ for $48 \mathrm{~h}$ at room temperature. The methanol extract of the plant was filtered and concentrated under reduced pressure in a rotary evaporator (Hanshin, Rotavapour) to get the crude oily extract $(84.83 \mathrm{~g})$. The crude extract was then fractionated successively with $n$-hexane, 
chloroform, ethyl acetate and water. The resulting fractionated extracts were concentrated and dried to get $n$-hexane extract (17.03 g), chloroform extract (3.63 g), ethyl acetate extract $(11.46 \mathrm{~g})$ and water extract $(22.67 \mathrm{~g})$. The chloroform extract was subjected to column chromatography over silica gel (60-120 mesh), eluted with different solvents of increasing polarity and four pure compounds I-IV were isolated. The structures of the compounds, were settled as 7-hydroxy-6methoxycoumarin (I), 5,7,4'-trimethoxykaempferol (II), 3,7,8,3,'4'-pentahydroxyflavone (III) and trans-[3-(4'hydroxyphenyl)-2-propenoic acid] (IV) by the exhaustive application of UV, IR, ${ }^{1} \mathrm{H}$ NMR, ${ }^{13} \mathrm{C}$ NMR, DEPT and mass spectral studies and comparing the data with those described in the literature ${ }^{11-14}$.

Compound I: Scopoletin (7-hydroxy-6-methoxycoumarin) $8.6 \mathrm{mg}$; white crystalline; $\mathrm{C}_{10} \mathrm{H}_{8} \mathrm{O}_{4} \mathrm{UV} \lambda_{\max }(\mathrm{MeOH}): 204$ (4.138) nm, 228 (3.824) nm, 252 (3.394) nm, 297 (3.384) nm, $344(3.728) \mathrm{nm}$; IR (KBr, $\left.v_{\max }, \mathrm{cm}^{-1}\right): 3339,1704,1565,1509$; ${ }^{1} \mathrm{H}$ NMR (300 MHz, $\left.\mathrm{CDCl}_{3}\right) \delta: 7.59(1 \mathrm{H}, \mathrm{d}, J=9.5 \mathrm{~Hz}, \mathrm{H}-4)$, $6.88(1 \mathrm{H}, \mathrm{s}, \mathrm{H}-8), 6.82(1 \mathrm{H}, \mathrm{s}, \mathrm{H}-5), 6.26(1 \mathrm{H}, \mathrm{d}, J=9.5 \mathrm{~Hz}$ $\mathrm{H}-3), 3.95$ (3H, s, -OMe); ${ }^{13} \mathrm{C} \mathrm{NMR}\left(75 \mathrm{MHz}, \mathrm{CDCl}_{3}\right) \delta: 161.38$ $(\mathrm{C}=\mathrm{O}), 150.3$ (C-8a), 149.7 (C-7), 144.01 (C-5a), 143.23(C3), 113.4(C-4), 111.5(C-6), 107.52 (C-8), 103.21(C-5), 56.43 $\left(-\mathrm{OCH}_{3}\right)$; mass: m/z $193[\mathrm{M}+\mathrm{H}]^{+}, 177,164,149,135,121$, 105,71 .

Compound II: 5,7,4'-Trimethoxykaempferol; $\mathrm{C}_{18} \mathrm{H}_{16} \mathrm{O}_{6}$; $6.8 \mathrm{mg}$; light yellow amorphous solid UV $\lambda_{\max }(\mathrm{MeOH}): 257$ (3.278), 296 (3.041) nm, 356 (3.204); IR ( $\left.\mathrm{KBr}, v_{\max }, \mathrm{cm}^{-1}\right)$ : 3463, 1732, 1609, 1511, 1460; ${ }^{1} \mathrm{H}$ NMR $\left(300 \mathrm{MHz}, \mathrm{CDCl}_{3}\right)$ $\delta: 8.17\left(2 \mathrm{H}, \mathrm{dd}, J=7\right.$ and $\left.2 \mathrm{~Hz}, \mathrm{H}-2^{\prime}, \mathrm{H}^{-} 6^{\prime}\right), 7.03$ (2H, dd, $J=$ 9 and $\left.2 \mathrm{~Hz}, \mathrm{H}-3^{\prime}, \mathrm{H}_{-} 5^{\prime}\right), 6.55(1 \mathrm{H}, \mathrm{d}, J=2.2 \mathrm{~Hz} \mathrm{H}-8), 6.35(1 \mathrm{H}$, d, $J=2.2 \mathrm{~Hz} \mathrm{H}-6), 3.98$ (3H, s, -OMe), 3.92 (3H, s, -OMe), 3.89 (3H, s, -OMe); mass: m/z $328[\mathrm{M}+\mathrm{H}]^{+}, 299,282,164$, $135,79$.

Compound III: 3,7,8,3'4'-Pentahydroxy flavone $\mathrm{C}_{15} \mathrm{H}_{10} \mathrm{O}_{7}$; $6.6 \mathrm{mg}$; light yellow amorphous solid UV $\lambda_{\max }(\mathrm{MeOH}): 203$ (4.307), 215 (4.041) nm, 323 (4.149); IR (KBr, $\left.\mathrm{n}_{\max }, \mathrm{cm}^{-1}\right)$ : 3163, 1702, 1606, 1509, 1457; ${ }^{1} \mathrm{H}$ NMR $\left(300 \mathrm{MHz}, \mathrm{MeOD}_{4}\right)$ $\delta: 7.81(1 \mathrm{H}, \mathrm{d}, J=9.5 \mathrm{~Hz}, \mathrm{H}-5), 7.41(1 \mathrm{H}, \mathrm{d}, J=8.5 \mathrm{~Hz}, \mathrm{H}-$ $\left.5^{\prime}\right), 6.75(1 \mathrm{H}, \mathrm{dd}, J=8.5$ and $2.2 \mathrm{~Hz} \mathrm{H}-6$ '), $6.67(1 \mathrm{H}, \mathrm{d}, J=2.2$ Hz H-2'), 6.14 (1H, d, J = 9.5 Hz, H-6); mass: m/z 302 [M+ - 1], 185.

Compound IV: Trans-[3-(4'-hydroxyphenyl)-2-propenoic acid]; $\mathrm{C}_{9} \mathrm{H}_{8} \mathrm{O}_{3} ; 6.3 \mathrm{mg}$; white amorphous solid; UV $\lambda_{\max }$ $(\mathrm{MeOH}) 222(3.633) \mathrm{nm}, 288(3.748) \mathrm{nm}$; IR (KBr, $\left.v_{\max }, \mathrm{cm}^{-1}\right)$ 3437, 2931, 1664, 1596, 1511, 1434 and 981; ${ }^{1} \mathrm{H}$ NMR (300 $\left.\mathrm{MHz}, \mathrm{MeOD}_{4}\right) \delta 7.49(1 \mathrm{H}, \mathrm{d}, J=15.9 \mathrm{~Hz}, \mathrm{H}-3), 7.34(2 \mathrm{H}, \mathrm{d}$, $J=8.6$ Hz H-2',H-6') 6.70 (2H, d, $J=8.5$ Hz H-3', H-5'), 6.18 $(1 \mathrm{H}, \mathrm{d}, J=15.9 \mathrm{~Hz} \mathrm{H}-2)$; mass: $\mathrm{m} / \mathrm{z} 164[\mathrm{M}+\mathrm{H}]^{+}, 147,119$, $118,91,65$.

\section{Antioxidant activity}

Total phenolic content: The total phenolic content of crude methanolic extract and four solvent extracts (hexane, chloroform, ethyl acetate and aqueous) was determined according to standard protoco ${ }^{15}$. Samples were introduced into test tubes; $1.0 \mathrm{~mL}$ of Folin-Ciocalteu reagent and $0.8 \mathrm{~mL}$ of sodium carbonate $(7.5 \%)$ were added. The tubes were mixed and allowed to stand for $0.5 \mathrm{~h}$. Absorption at $765 \mathrm{~nm}$ was measured (Ultrospec 2000 UV-visible spectrophotometer, Pharmacia Biotech, USA). The total phenolic content was expressed as gallic acid equivalents (GAE) in microgram per mg of extract.

DPPH Radical scavenging activity: The DPPH radical scavenging activity of the crude extract, four solvent extracts and isolated four compounds was determined according to standard protocol ${ }^{15}$. The free radical scavenging activity of different extracts and butylated hydroxyl toluene (BHT) as positive control was determined using the stable radical DPPH (2,2-diphenyl-1-picrylhydrazyl). Aliquots (20-100 mL) of the tested sample were placed in test tubes and $3.9 \mathrm{~mL}$ of freshly prepared DPPH solution $(25 \mathrm{mg} / \mathrm{L})$ in methanol was added in each test tube and mixed. $0.5 \mathrm{~h}$ later, the absorbance was measured at $517 \mathrm{~nm}$. The capability to scavenge the DPPH radical was calculated using the following equation:

$$
\text { DPPH scavenged }(\%)=\left\{\frac{\left(A_{c}-A_{t}\right.}{A_{c}}\right\} \times 100
$$

where $A_{c}$ is the absorbance of the control reaction and $A_{t}$ is the absorbance in presence of the sample of the extracts. The antioxidant activity of the extract was expressed as $\mathrm{IC}_{50}$. Each value was determined from regression equation.

\section{Antiinflammatory activity}

Animal: Adult male inbred albino rats (Wister Strain) weighing between 150-175 $\mathrm{g}$ and male mice weighing between 20-22 g were used for anti-inflammatory and acute toxicity study, respectively. They were fed on commercial diet (Hindustan Lever) and water ad libitum. All the animals were acclimatized for a week before use. The room temperature was maintained at $25 \pm 1{ }^{\circ} \mathrm{C}$. The experimental protocol was approved by Institutional Animal Ethical Committee (IAEC Reg. 507).

Acute toxicity: Methanolic extract and four solvent extracts (hexane, chloroform, ethylacetate and aqueous) were fed and injected to the mice orally and intraperitoneally to determine lethality or morbidity within 3 days. The dose was given in progressive manner ${ }^{16}$.

Study of antiinflammatory activity using carrageenan induced paw edema in rat: Acute inflammation was induced by carrageenan according to the model of Winter et al. ${ }^{17}$ with slight modification ${ }^{18}$. For this purpose, $0.1 \mathrm{~mL}$ of $1 \%$ suspension of carrageenan in normal saline was injected into the subplantar tissues of right hind paw in rats. The right paw volume was plethysmometrically (Techno, India) measured at 0 and $3 \mathrm{~h}$ after carrageenan injection. The test extracts were administered at dose of 250 and $500-\mathrm{mg} / \mathrm{kg}$ body weight, orally, $1 \mathrm{~h}$ before experiment. Diclofenac sodium $(10 \mathrm{mg} / \mathrm{kg}$, p.o.) was used as standard, while $0.9 \% \mathrm{NaCl}(2.5 \mathrm{~mL} / \mathrm{kg}$, p.o.) was given to control animals. The antiinflammatory activity was expressed as the average percent inhibition of edema in each group, which was calculated according to the general formula :

$$
\text { Inhibition }(\%)=100-\left(100 \times \frac{\mathrm{V}_{\mathrm{t}}}{\mathrm{V}_{\mathrm{c}}}\right)
$$

where, $\mathrm{V}_{\mathrm{t}}$ and $\mathrm{V}_{\mathrm{c}}$ represent the increase in paw volumes of rats treated with drug and control, respectively. 


\section{RESULTS AND DISCUSSION}

The total phenolic content and the DPPH radical scavenging activities of the different solvent extracts of the plant Ipomoea pes-caprae are reported in Table-1. The antioxidant status of the chloroform (379.8 $\mu \mathrm{g}$ GAE/ mg extract and $\mathrm{IC}_{50} 1390 \mu \mathrm{g} /$ $\mathrm{mL})$ and ethylacetate extracts $(973.16 \mu \mathrm{g} \mathrm{GAE} / \mathrm{mg}$ extract and $\mathrm{IC}_{50} 340 \mu \mathrm{g} / \mathrm{mL}$ ) of the plant was found to be promising, hence these were subjected to antiinflammatory activity assay, the results of which are recorded in Table-2. The active ethyl acetate

\begin{tabular}{|c|c|c|}
\hline \multicolumn{3}{|c|}{$\begin{array}{c}\text { TABLE-1 } \\
\text { TOTAL PHENOLIC CONTENT AND DPPH RADICAL } \\
\text { SCAVENGING ACTIVITY OF Ipomoea-pes-caprae }\end{array}$} \\
\hline Sample & $\begin{array}{c}\text { Total phenolic } \\
\text { content }(\mu \mathrm{g} \mathrm{GAE} / \mathrm{mg} \\
\text { extract })\end{array}$ & $\begin{array}{l}\text { DPPH radical } \\
\text { scavenging activity } \\
\left(\mathrm{IC}_{50} \text { in } \mu \mathrm{g} / \mathrm{mL}\right)\end{array}$ \\
\hline Methanolic extract & $0.189 \pm 0.001$ & $1520 \pm 44.01$ \\
\hline Hexane extract & $94.67 \pm 0.87$ & $5130 \pm 69.01$ \\
\hline Chloroform extract & $379.80 \pm 6.67$ & $1390 \pm 8.12$ \\
\hline Ethylacetate extract & $973.16 \pm 1.46$ & $340 \pm 3.14$ \\
\hline Aqueous extract & $40.98 \pm 0.58$ & $5580 \pm 130.12$ \\
\hline
\end{tabular}

\begin{tabular}{|c|c|c|c|}
\hline \multicolumn{4}{|c|}{$\begin{array}{c}\text { TABLE-2 } \\
\text { ANTIINFLAMMATORY ACTIVITY OF Ipomoea pes-caprae }\end{array}$} \\
\hline Drug/extracts & $\begin{array}{c}\text { Doses } \\
(\mathrm{mg} / \mathrm{k} \\
\mathrm{g})\end{array}$ & $\begin{array}{c}\text { Paw volume } \\
\text { increased in } 3 \\
\mathrm{~h}(\mathrm{cc})\end{array}$ & $\begin{array}{c}\text { Edema (\%) } \\
\text { inhibition relative } \\
\text { to control at } 3 \mathrm{~h}\end{array}$ \\
\hline Control & 2.5 & $1.08 \pm 0.092$ & - \\
\hline Methanolic extract & $\begin{array}{l}250 \\
500\end{array}$ & $\begin{array}{l}0.76 \pm 0.074^{* * *} \\
0.48 \pm 0.065^{* * *}\end{array}$ & $\begin{array}{l}29.62 \\
55.55\end{array}$ \\
\hline Chloroform extract & $\begin{array}{l}250 \\
500\end{array}$ & $\begin{array}{l}0.68 \pm 0.041^{* * *} \\
0.46 \pm 0.029^{* * *}\end{array}$ & $\begin{array}{l}37.04 \\
57.41\end{array}$ \\
\hline Ethyl acetate extract & $\begin{array}{l}250 \\
500\end{array}$ & $\begin{array}{l}0.62 \pm 0.083^{* * *} \\
0.43 \pm 0.051^{* * *}\end{array}$ & $\begin{array}{l}42.59 \\
60.20\end{array}$ \\
\hline Diclofenac sodium & 10 & $0.38 \pm 0.052^{* * *}$ & 64.81 \\
\hline
\end{tabular}

extract was found to have the highest antiinflammatory activity (42.59 and $60.20 \%$ inhibition at 250 and $500 \mathrm{mg} / \mathrm{kg}$ doses) followed by chloroform extract (37.04 and $57.41 \%$ inhibition at 250 and $500 \mathrm{mg} / \mathrm{kg}$ doses) (Table-2). The potency of the crude extract and four solvent extracts was observed more in higher doses. It may be mentioned that the antiinflammatory activity of the chloroform and ethylacetate extract was better than that reported by Pongprayoon et al. ${ }^{6,7}$ (54.68\% inhibition). This may be due to ecological influence on the plant. The methanolic extract and other four solvent extracts of the plant did not show any signs of toxicity up to $2 \mathrm{~g} / \mathrm{kg}$ body weight per oral and i.p. dose in mice. Hence, these were quite safe for use. Individual assay of the isolated compounds (Fig. 1) showed that compound IV possesses highest radical scavenging activity $(795.72 \mu \mathrm{g} / \mathrm{mL})$ followed by compound III $(1311.02 \mu \mathrm{g} / \mathrm{mL})$, compound II $(2148.06 \mu \mathrm{g} / \mathrm{mL})$ and compound I $(3027.99 \mu \mathrm{g} / \mathrm{mL})$ as is evident from the bar diagram (Fig. 2). Several compounds had been reported from hexane, petroleum ether and ethylacetate extract of I. pescaprae $^{6,19-24}$ but there was no report regarding the isolation
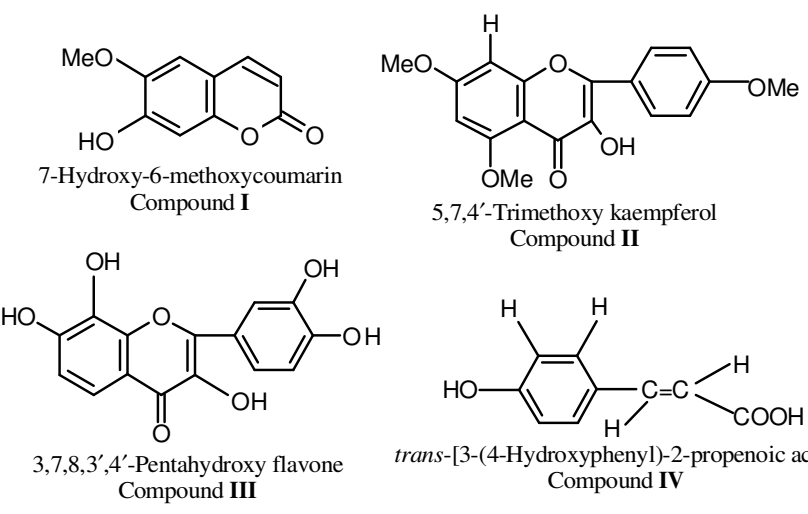

Fig. 1. Compounds (I-IV) isolated from Ipomoea pes-caprae

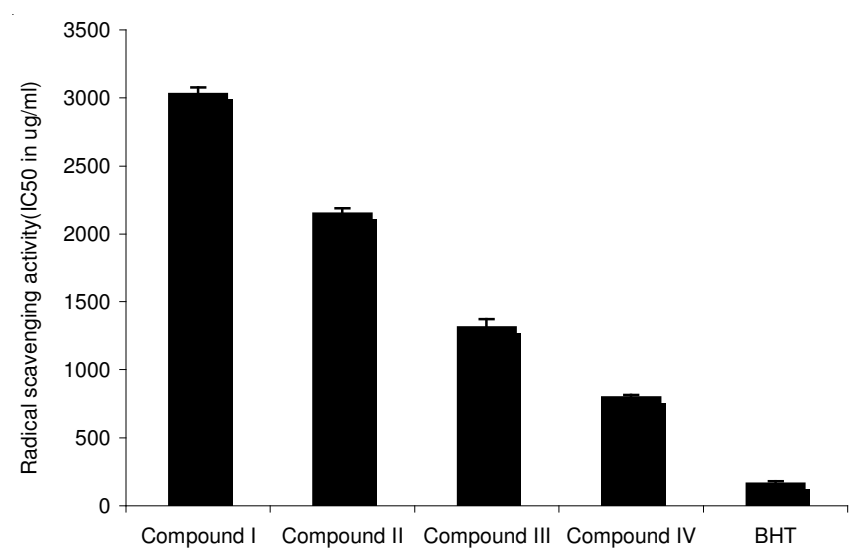

Fig. 2. DPPH radical scavenging activity of compounds (I-IV) isolated from Ipomoea pes-caprae and $\mathrm{BHT}$

of these four compounds from I. pes-caprae. All these compounds isolated from other sources were shown to possess antiinflammatory activity ${ }^{11,25-27}$, further strengthening our observation.

\section{Conclusion}

Hence, the folkloric use of Ipomoea pes-caprae in the Sunderban area is scientifically justified.

\section{ACKNOWLEDGEMENTS}

The authors are grateful to Ministry of Earth Sciences, Government of India for funding. Thanks are also due to Botanical Survey of India, Kolkata, for identifying the plant species.

\section{REFERENCES}

1. C.P. Locher, M. Burch, H.F. Mower, J. Berestecky, H. Davis, B.Van-Poel, A. Lasure, D.A. Vanden-Berghe and A.J. Vlietinck, J. Ethnopharmacol., 49, 23 (1995).

2. M.M. Souza, A.M. Oliveira, V. Cechinel Filho, C. Berti, R.A. Yunes and R. Krogh Estudos, Alcance, (Univali), 5, 53 (1998).

3. U. Pongprayoon, L. Bohlin and F. Sandberg, Acta Pharm. Nordica, 1, 41 (1989).

4. M.M. Khan, F. Ahmad, A.K. Rastogi and J.R. Kidwai, Fitoterapia, 65, 231 (1994).

5. R. Krogh, R. Kroth, C. Berti, A.O. Madeira, M.M. Souza, V. CechinelFilho, F. DelleMonache and R.A. Yunes, Pharmazie, 54, 464 (1999).

6. U. Pongprayoon, P. Baeckstrom, U. Jacobsson, M. Lindstroem and L. Bohlin, Planta Med., 58, 19 (1992).

7. U. Pongprayoon, P. Baeckstorm, U. Jacobsson, M. Lindstorm and L. Bohlin, Planta Med., 57, 516 (1991). 
8. U. Pongprayoon, L. Bohlin and S. Wasuwat, J. Ethnopharmacol., 35, 65 (1991).

9. M.M. De Souza, A. Madeira, C. Bert, R. Krogh and R.A. Yunes, J. Ethanopharmacol., 69, 85 (2000).

10. K Naskar and D.N. Guha Bakshi, Mangrove Swamps of the Sundarbans: An Ecological Perspective, Naya Prokash, Calcutta, India, p. 206 (1995).

11. J.H. Wu, Y.T. Tung, S.C. Chien, S.Y. Wang, Y.H. Kuo, L.F. Shyur and S.T. Chang, J. Agric. Food Chem., 56, 1567 (2008).

12. C. Ito and H. Furukawa, Chem. Pharm. Bull., 35, 4277 (1987).

13. A. Jeffrey Smith, J. David Maloney, M. Sidney Hecht and A. Deborah Lannigan, Bioorg. Med. Chem., 15, 5018 (2007).

14. M.M. Hussain, M.S. Rahman, A. Jabbar and M.A. Rashid, Med. Aromat., 7, 273 (2008).

15. D. Banerjee, S. Chakrabarti, A.K. Hazra, S. Banerjee, J. Ray and B. Mukherjee, Afr. J. Biotechnol., 7, 805 (2008).

16. H.J. Horn, Biometrics, 12, 312 (1956).

17. C.A. Winter, E.A. Risley and G.W. Nuss, Proc. Soc. Exp. Biol. Ther., 111, 544 (1962).
18. T.K Sur, T.K. Biswas, L Ali and B. Mukherjee, Acta Pharmacol. Sin., 24, 187 (2003).

19. U. Pongprayoon, P. Baeckstorm, U. Jacobsson, M. Lindstorm and L. Bohlin, Planta Med., 57, 516 (1991).

20. F. Teramachi, T. Koyano, T. Kowithayakorn, M. Hayashi, K. Komiyama and M. Ishibashi, J. Nat. Prod., 68, 794 (2005).

21. R.P. Miranada, E.E. Sanchez and C.E. Martinez, J. Nat. Prod., 68, 226 (2005).

22. U. Pongprayoon, P. Baeckstrom, U. Jacobsson, M. Lindstroem and L. Bohlin, Planta Med., 58, 19 (1992).

23. R. Srivastava, K. Sachdev, P. Kunath Madhusudanan and K Dinesh Kulshreshtha, Carbohydr. Res., 212, 169 (1991).

24. E.P.M. Daniel, D. Brkie and Q.-L. Joelle, Nat. prod. Commun., 2, 1225 (2007).

25. A. Panthong, D. Kanjanapothi, P. Tuntiwachwuttikul, O. Pancharoen and V. Reutrakul, Phytomedicine, 1, 141 (1994).

26. C. Luceri, L. Giannini, M. Lodovici, E. Antonucci, R Abbate and E.D. Masini, Br. J. Nutr., 97, 458 (2007).

27. R. Gautam and S.M. Jachak, Med Res Rev., 29, 767 (2009). 